\title{
Spectrophotometric Determination of Cerium (III) with Arsenazo III: Application to Sea Water and Synthetic Alloys
}

Sadallah T. Sulaiman

\author{
Ghaydaa K. Hanna \\ Department of Chemistry \\ College of Science \\ University of Mosul
}

Wadala A. Bashir

(Received 21/5/2012;Accepted 10/9/2012)

\section{ABSTRACT}

The detailed investigation of a sensitive and selective spectrophotometric method for the determination of trace amounts of cerium is described. The method is based on the reaction of cerium(III) with arsenazo $w$ in the presence of sodium dodecyl sulphate surfactant at $\mathrm{pH} 3.0$ to form a blue-greenish coloured chelate absorbing maximum at $653 \mathrm{~nm}$. Beer's law is obeyed over the range (5-70) $\mu \mathrm{g} / 25 \mathrm{ml}$, with a molar absorptivity of $\left(4.99 \times 10^{4}\right) 1 . \mathrm{mol}^{-}$ ${ }^{1} . \mathrm{cm}^{-1}$ and the coefficient of determination $\left(\mathrm{r}^{2}\right)$ is 0.9994 , Sandell's sensitivity index is $\left(28.08 \times 10^{-4}\right) \mu \mathrm{g} . \mathrm{cm}^{-2}$, a relative error of $(0.0-0.2 \%)$ and a relative standard deviation of $(0.0$ to $+2.1) \%$, depending on the concentration levels in the calibration curve. The method has been applied successfully to determine cerium in sea water and some synthetic alloys.

Keywords: Ce(III) determination ; Arsenazo III reagent ; Sodium dodecyl sulphate ; Spectrophotometry.

\section{القير اللمي السيريوم الثلاثي بكاثف الوسن آزو - الظبيق عل ماء البحر والسبال المصنهة}

\section{ll}

لقد مق ظويرطريقة طيفية هسلسة والنقائية لقدير كميلت متناهية في الصغر من اليون اللسيريوم الثلاثي مع كلثف الاسين ازو الثلاثي بوجود كبريتت الصوديوم الدويكالية عند دالة حلمضية 3.0 لتكوين

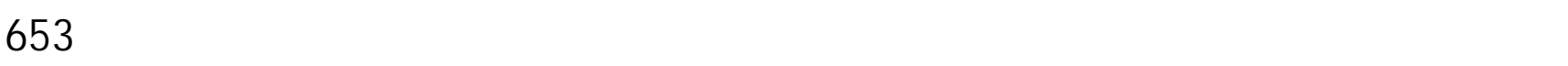

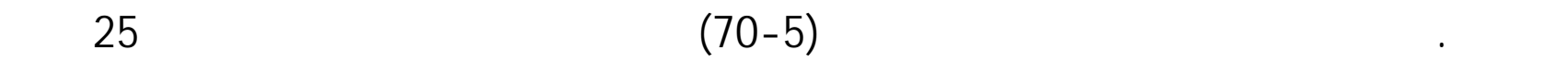

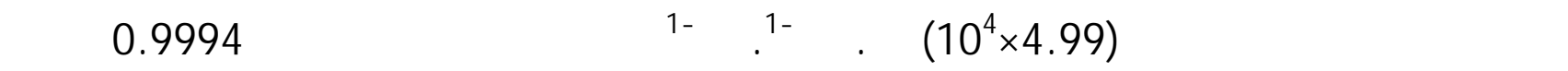

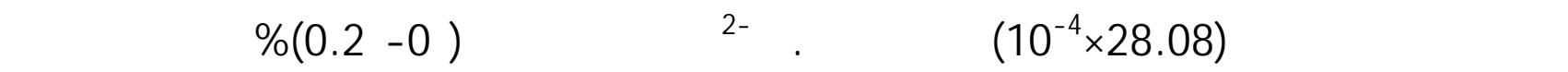

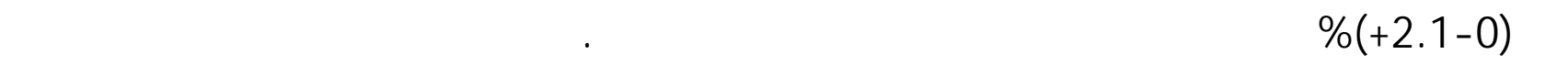
الثلاثي في بعض اللسباءs المصنعة وماء البحر. 


\section{INTRODUCTION}

Cerium is the most abundant rare earth element, and is a silvery metal, belonging to the lanthanide group. Cerium is especially interesting because of its variable electronic structure. It tarnishes slowly in air and burns readily at $150^{\circ} \mathrm{C}$ to form cerium oxide. Cerium is quite electropositive and reacts slowly with cold water and quite quickly with hot water to form cerium hydroxide (Internet, 2009).

Cerium (III) chloride is used to facilitate reactions of carbonyl groups in organic chemistry. The metal itself was too electropositive to be isolated by the current smelting technology, a characteristic of rare earth metal in general. Cerium alloys are used in permanent magnets and in tungsten electrodes for gas tungsten arc welding. Cerium is used in carbon-arc lighting, especially in the motion picture industry (Hammond, 2000).

Cerium is a strong reducing agent, workers exposed to cerium have experienced itching, sensitivity to heat and skin lesions. Animals injected with large doses of cerium have died due to cardiovascular collapse (Alessandro, 2002). Therefore, determination of cerium is of considerable importance.

Sodium triphosphate acts as specific reagent for enhancing the fluorescence intensity of $\mathrm{Ce}(\mathrm{III})$. The excitation and emission wavelengths are $303.5 \mathrm{~nm}$ and $353 \mathrm{~nm}$, respectively. The fluorescence varies linearly with the concentration of cerium(III) in the range (0.00145) $\mu \mathrm{g} \mathrm{ml}^{-1}$, the detection limit is $\left(9.4 \times 10^{-4}\right) \mu \mathrm{g} \mathrm{ml}^{-1}$. The relative standard deviations for 30 $\mu \mathrm{g} \mathrm{ml}^{-1}$ and $0.05 \mu \mathrm{g} \mathrm{ml}^{-1}$ are $1.1 \%$ and $0.72 \%$, respectively, (Ayglgek and Rakicioglu,1996).

A new ion-selective electrode for cerium(III) ions based on a new ligand, N-[(Z)-2chloro-2-(1-hydroxy-1,1,1-triphenylphosphoranyl)-1-ethenyl]-4-ethyl-1-benzene sulphonamide, as ionophore was prepared. The electrode has a wide linear dynamic range $\left(6.6 \times 10^{-7}\right.$ to $\left.6.2 \times 10^{-2} \mathrm{M}\right)$, with a low detection limit $\left(2.3 \times 10^{-7} \mathrm{M}\right)$. This sensor was applied to determination of fluoride ion in pharmaceutical samples and of cerium content in stainless steel samples (Karami, 2003). Trace amounts of cerium were analyzed by flow injectionkinetic spectrophotometry. The determination of Ce (IV) in the range $0-8.0 \mu \mathrm{g} \mathrm{ml}^{-1}$, with a correlation coefficient (r) of 0.9982 was obtained. The proposed method was applied to analyze $\mathrm{Ce}$ in soil successfully (Zhu et al., 2008). Colorimetric method for the determination of cerium (IV) ions with ampicillin and amoxicillin has been worked out. Beer's Law is obeyed in the concentration range from 2.5 to $25 \mu \mathrm{g}$ and from 2 to $10 \mu \mathrm{g}$ in $25 \mathrm{ml}$ for ampicillin and amoxicillin, respecitively. The absorbance was measured at $\lambda_{\max }=$ $655 \mathrm{~nm}$ at $\mathrm{pH} 3.2-3.6$. The molar absorptivity was found to be $2.7 \times 10^{5} 1 . \mathrm{mol}^{-1} \mathrm{~cm}^{-1}$ for ampicillin and $5.2 \times 10^{5} 1 . \mathrm{mol}^{-1} \mathrm{~cm}^{-1}$ for amoxicillin (Franciszek et al., 2001).

The determination of Ce (III) ions using octadecyl-bonded silica membrane discs modified with 1,3,5-trithiacyclohexane (TTCH) and spectrophotometry with arsenazo III was accomplished (Shamsipur et al., 2002).

The present article is devoted to develop a spectrophotometric method to determination of cerium (III) ion using arsenazo III (scheme 1) as a chromo-genic reagent [arsenazo III is 2,7-bis(arsenophenylazo)-1,8-dihydroxy-3,6-naphthalenedisulfonic acid] in the presence of sodium dodecyl sulphate as surfactant. 
<smiles>O=C(O)c1ccccc1N=Nc1c(S(=O)(=O)O)cc2cc(S(=O)(=O)O)c(/N=N/c3ccccc3S(=O)(=O)O)c(O)c2c1O</smiles>

\section{Scheme 1. Arsenazo II structure}

\section{EXPERIMENTAL}

\section{Apparatus}

Spectral and absorbance measurements were carried out using Shimazu UV-160 spectrophotometer with $1-\mathrm{cm}$ matched quartz cells while the $\mathrm{pH}$ measurements were carried out using HANNA pH-211 pH meter.

\section{Reagents}

All chemicals used are of the highest purity available.

Stock cerium(III) $(100 \mu \mathrm{g} / \mathrm{ml})$ solution.

This solution was prepared by dissolving $0.0266 \mathrm{~g}$ of cerium chloride heptahydrate (Hopkin and Williams) in distilled water and the volume was completed to $100 \mathrm{ml}$ with distilled water in a volumetric flask.

Working cerium( $\mathrm{HI})(50 \mu \mathrm{g} / \mathrm{ml})$ solution.

This solution was prepared by diluting $50 \mathrm{ml}$ of the above stock cerium(ш) solution to $100 \mathrm{ml}$ in a volumetric flask with distilled water.

\section{Arsenazo III reagent $\left(\mathrm{Az}\right.$ III) $\left(1 \times 10^{-4} M\right)$ solution.}

It was prepared by dissolving $0.0194 \mathrm{~g}$ of arsenazo $\mathrm{w}$ (Fluka) in distilled water and the solution was diluted to $250 \mathrm{ml}$ in a volumetric flask and then transferred to a dark bottle, where it is stable for at least five days.

\section{Buffer solution (pH3).}

This solution was prepared by mixing $50 \mathrm{ml}$ of $0.1 \mathrm{M}$ glycine solution and $5.7 \mathrm{ml}$ of $0.2 \mathrm{M} \mathrm{HCl}$ and the volume was completed to $100 \mathrm{ml}$ with distilled water in a volumetric flask (Perrin and Dempsey, 1974).

Sodium dodecyl sulphate $(\mathrm{SDS})\left(1 \times 10^{-3} M\right)$ solution.

This solution was prepared by dissolving $0.0288 \mathrm{~g}$ of sodium dodecyl sulphate (BDH) in distilled water and the volume is completed to $100 \mathrm{ml}$ in a volumetric flask.

\section{Interfering ion solutions.}

A100 $\mu \mathrm{g} / \mathrm{ml}$ solution of each ion tested was prepared in distilled water.

\section{Synthetic sea water.}

It was prepared as described (Herkinson, 1965) by dissolving $2.2 \mathrm{~g} \mathrm{NaCl}, 9.7 \mathrm{~g}$ $\mathrm{MgCl}_{2} .6 \mathrm{H}_{2} \mathrm{O}, 3.7 \mathrm{~g} \mathrm{Na}_{2} \mathrm{SO}_{4}, 1 \mathrm{~g} \mathrm{CaCl}_{2}, 0.65 \mathrm{~g} \mathrm{KCl}, 0.17 \mathrm{~g} \mathrm{NaHCO}_{3}$ and $0.023 \mathrm{~g} \mathrm{H}_{3} \mathrm{BO}_{3}$ in about $500 \mathrm{ml}$ of distilled water, then the resulted solution diluted to $1 \mathrm{~L}$ with distilled water in a volumetric flask. 


\section{RESULTS AND DISCUSSION}

For subsequent experiments, $50 \mu \mathrm{g}$ of $\mathrm{Ce}(ш)$ ion were taken and final volumes were 25 $\mathrm{ml}$.

\section{Preliminary investigations}

The visible spectra of the blue-greenish coloured chelate were measured immediately after mixing $50 \mu \mathrm{g}$ of cerium (ш) solution (M), $3 \mathrm{ml}$ of $\left(1 \times 10^{-4} \mathrm{M}\right)$ arsenazo $ш(\mathrm{R})$ and $1 \mathrm{ml}$ of $0.01 \mathrm{M} \mathrm{HCl}$ and showed an absorption band at $653 \mathrm{~nm}$, which indicates a definite reaction between $\mathrm{Ce}$ (ш) and Az $ш$ reagent in contrast with the reagent blank which shows maximum absorption at $537 \mathrm{~nm}$. The reaction shows good colour contrast $(\Delta \lambda=116 \mathrm{~nm})$. The wavelength at $653 \mathrm{~nm}$ has been selected for the subsequent experiments because: (a) the absorbance is higher, (b) the absorbance of the blank is lower.

\section{Study of the optimum reaction conditions}

The effect of various parameters on the absorption intensity of the coloured complex as studied and the optimum conditions have been selected for determination of cerium (ш) with arsenazo ш.

\section{Effect of pH}

The influence of $\mathrm{pH}$ on the colour intensity of the complex formed has been studied by transferring $50 \mu \mathrm{g}$ of cerium (ш) ion solution, $5 \mathrm{ml}$ of $1 \times 10^{-4} M$ solution of arsenazo ш reagent and different volumes of $0.01 \mathrm{M} \mathrm{HCl}$ and $0.01 \mathrm{M} \mathrm{NaOH}$, separately. The volumes are then completed to $25 \mathrm{ml}$, in volumetric flasks, with distilled water. The absorbance was measured at $653 \mathrm{~nm}$ for each solution and the final $\mathrm{pH}$ is taken. The results obtained are presented in Table 1.

Table 1: Effect of pH on absorbance

\begin{tabular}{|c|c|c|c|c|}
\hline \multirow{2}{*}{\begin{tabular}{c} 
ml of acid $\begin{array}{c}\text { Absorbance/ml of acid or base added } \\
\text { solution added }\end{array}$ \\
\cline { 2 - 5 }
\end{tabular}} & \multicolumn{3}{|c|}{ HCl (0.01M) } & \multicolumn{2}{c|}{ NaOH (0.01M) } \\
\hline \multirow{2}{*}{$\mathrm{A}$} & $\mathrm{pH}$ & $\mathrm{A}$ & $\mathrm{pH}$ \\
\hline 1 & 0.407 & 5.2 & 0.407 & 5.2 \\
\hline 2 & 0.693 & 3.5 & 0.245 & 10.2 \\
\hline 3 & 0.717 & 3.2 & 0.186 & 10.6 \\
\hline 4 & 0.712 & 3.0 & 0.137 & 10.9 \\
\hline 5 & 0.665 & 2.9 & 0.110 & 11.1 \\
\hline 6 & 0.648 & 2.8 & 0.093 & 11.3 \\
\hline 7 & 0.623 & 2.7 & 0.045 & 11.4 \\
\hline 8 & 0.612 & 2.7 & 0.015 & 11.4 \\
\hline 9 & 0.605 & 2.6 & 0.013 & 11.5 \\
\hline 10 & 0.537 & 2.6 & 0.012 & 11.6 \\
\hline & 0.522 & 2.6 & 0.009 & 11.7 \\
\hline
\end{tabular}

From Table (1), the higher absorbance is observed in acidic medium at $\mathrm{pH}$ 3.2-3.0. In basic medium, the sensitivity has been lowered and accompanied by a weak contrast. In the subsequent experiments, $\mathrm{pH} 3$ has been selected as optimum and therefore, different buffers 
(Perrin and Dempsey, 1974) corresponding to the above optimum $\mathrm{pH}$ have been sought for their greater capacity as well. The experimental results are represented in Table (2).

The following buffers were made (100 $\mathrm{ml}$ in volumetric flasks).

B1(pH 2.8): (44.2 $\mathrm{ml}$ of $2 \mathrm{M}$ formic acid and $5 \mathrm{ml}$ of $2 \mathrm{M} \mathrm{NaOH}$ ).

B1(pH 3.0): (29.4 $\mathrm{ml}$ of $2 \mathrm{M}$ formic acid and $5 \mathrm{ml}$ of $2 \mathrm{M} \mathrm{NaOH})$.

B2(pH 3.0): (50 ml of 0.1M KHP and $22.3 \mathrm{ml}$ of $0.1 \mathrm{M}$ of $\mathrm{HCl})$.

$\mathrm{B} 3(\mathrm{pH} 3.0)$ : (10 $\mathrm{ml}$ of $2 \mathrm{M}$ tartaric acid and $7 \mathrm{ml}$ of $2 \mathrm{M} \mathrm{NaOH})$.

B4(pH 3.0): (10 $\mathrm{ml}$ of $2 M$ citric acid and $6 \mathrm{ml}$ of $2 \mathrm{M} \mathrm{NaOH})$.

B5(pH 2.8): $(50 \mathrm{ml}$ of $0.1 \mathrm{M}$ glycine and $8.4 \mathrm{ml}$ of $0.2 \mathrm{M} \mathrm{HCl})$.

B5(pH 3.0): $(50 \mathrm{ml}$ of $0.1 M$ glycine and $5.7 \mathrm{ml}$ of $0.2 \mathrm{M} \mathrm{HCl})$.

B5(pH 3.2): (50 ml of $0.1 M$ glycine and $4.1 \mathrm{ml}$ of $0.2 \mathrm{M} \mathrm{HCl})$.

Table 2: Effect of different buffers on absorbance

\begin{tabular}{|c|c|c|c|c|c|c|c|c|c|c|c|c|c|c|c|c|}
\hline \multirow{3}{*}{$\begin{array}{c}\text { ml of } \\
\text { buffer } \\
\text { solution }\end{array}$} & \multicolumn{16}{|c|}{ Absorbance/ $\mathrm{ml}$ of buffer added } \\
\hline & \multicolumn{2}{|c|}{$\mathrm{B}_{1}(\mathrm{pH} 2.8)$} & \multicolumn{2}{|c|}{$\mathrm{B}_{1}(\mathrm{pH} 3)$} & \multicolumn{2}{|c|}{$\mathrm{B}_{2}(\mathrm{pH} 3)$} & \multicolumn{2}{|c|}{$\mathrm{B}_{3}(\mathrm{pH} 3)$} & \multicolumn{2}{|c|}{$\mathrm{B}_{4}(\mathrm{pH} 3)$} & \multicolumn{2}{|c|}{$\mathrm{B}_{5}(\mathrm{pH} 2.8)$} & \multicolumn{2}{|c|}{$\mathrm{B}_{5}(\mathrm{pH} 3)$} & \multicolumn{2}{|c|}{$\mathrm{B}_{5}(\mathrm{pH} 3.2)$} \\
\hline & A & $\mathrm{pH}$ & A & $\mathrm{pH}$ & A & $\mathrm{pH}$ & A & $\mathrm{pH}$ & A & $\mathrm{pH}$ & A & $\mathrm{pH}$ & A & $\mathrm{pH}$ & A & $\mathrm{pH}$ \\
\hline 0 & 0.41 & 5.2 & 0.41 & 5.2 & 0.41 & 5.2 & 0.41 & 5.2 & 0.41 & 5.2 & 0.41 & 5.2 & 0.41 & 5.2 & 0.41 & 5.2 \\
\hline 1 & 0.65 & 3.2 & 0.61 & 3.3 & 0.63 & 3.3 & 0.55 & 3.5 & 0.51 & 3.3 & 0.68 & 3.3 & 0.69 & 3.3 & 0.66 & 3.5 \\
\hline 2 & 0.63 & 3.2 & 0.60 & 3.3 & 0.64 & 3.3 & 0.54 & 3.5 & 0.43 & 3.3 & 0.69 & 3.3 & 0.72 & 3.2 & 0.67 & 3.4 \\
\hline 3 & 0.63 & 3.2 & 0.59 & 3.3 & 0.65 & 3.2 & 0.51 & 3.5 & 0.38 & 3.3 & 0.69 & 3.2 & 0.73 & 3.2 & 0.66 & 3.5 \\
\hline 4 & 0.63 & 3.2 & 0.56 & 3.2 & 0.65 & 3.2 & 0.48 & 3.5 & 0.33 & 3.3 & 0.66 & 3.2 & 0.70 & 3.2 & 0.65 & 3.5 \\
\hline 5 & 0.59 & 3.2 & 0.55 & 3.2 & 0.61 & 3.2 & 0.45 & 3.5 & 0.33 & 3.2 & 0.66 & 3.2 & 0.68 & 3.3 & 0.64 & 3.5 \\
\hline
\end{tabular}

From the results in Table (2), $3 \mathrm{ml}$ of glycine- $\mathrm{HCl}$ (B5) (pH 3.0) buffer solution was chosen for the subsequent work, since it gives a good absorbance for the standard and lower blank value.

\section{Effect of reagent amount:}

The effect of arsenazo $\amalg$ reagent amount on maximum formation of the coloured complex is investigated. A $7 \mathrm{ml}$ of $1 \times 10^{-4} M$ arsenazo $ш$ reagent is recommended as optimal value for the following experiments because of its highest sensitivity and relatively lower blank value as shown in Table (3).

Table 3: Effect of the reagent amount on absorbance

\begin{tabular}{|c|c|c|}
\hline $\begin{array}{c}\text { ml of } 1 \times 10^{-4} M \\
\text { Az wi reagent } \\
\text { solution } \\
\end{array}$ & $\mathbf{A}_{\text {B }}^{\mathbf{S}}$ & $\mathbf{A}^{\mathbf{B}}$ \\
\hline 1 & 0.155 & 0.003 \\
\hline 3 & 0.438 & 0.008 \\
\hline 4 & 0.569 & 0.009 \\
\hline 5 & 0.693 & 0.010 \\
\hline 7 & 0.801 & 0.015 \\
\hline 10 & 0.702 & 0.026 \\
\hline
\end{tabular}




\section{Effect of surfactants}

The effect addition of different types of surfactants on the optical properties of the coloured chelated complex was studied. The experimental data reveal that only $1.5 \mathrm{ml}$ of $1 \times 10^{-3} \mathrm{M}$ of sodium dodecyl sulphate (SDS) solution was useful when added before buffer (Cerium(ш) ion + Arsenazo $ш$ reagent + SDS + pH3 glycine buffer) and diluted to the mark (Fig.1).

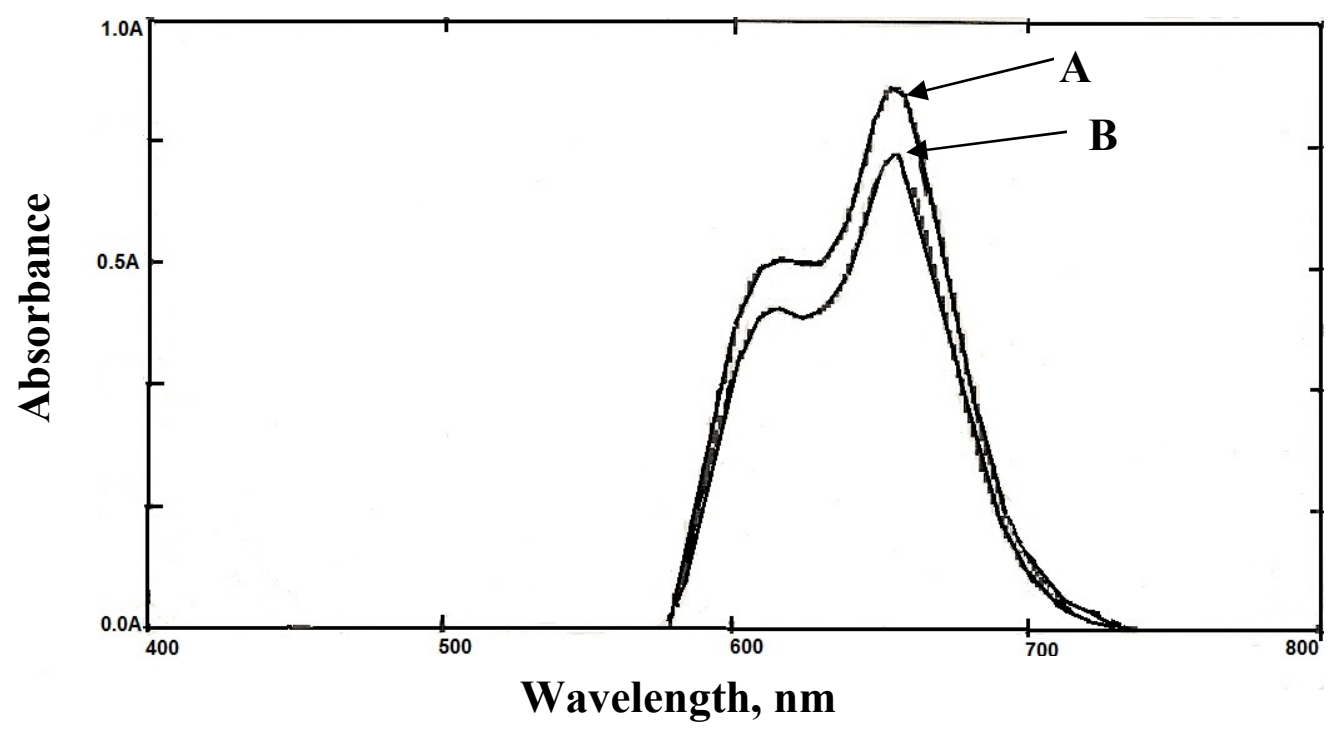

Fig. 1: Absorption spectra of Ce(II)-Az III complex. (A): in the presence of SDS,

(B): in the absence of SDS.

The enhancing effect (Fig. 1) of the SDS surfactant may indicate that the formed chelate has acquired a positive charge. The cationic surfactants destroy the chelate due to charge repulsion.

\section{Effect of time}

The effect of time on the colour intensity of the $\mathrm{Ce}(\omega)-\mathrm{Az} \omega$ chelate complex produced from different amounts of cerium( $ш)$ ion has been explored. The results are shown in Table (4).

Table 4: Effect of time on absorbance.

\begin{tabular}{|c|c|c|c|c|c|c|}
\hline Time & \multicolumn{7}{|c|}{ Absorbance/ $\boldsymbol{\mu g}$ Ce(II) added } \\
\hline (min) & 5 & 10 & 30 & 50 & 70 & 100 \\
\hline 5 & 0.065 & 0.119 & 0.427 & 0.726 & 0.992 & 0.995 \\
\hline 10 & 0.072 & 0.118 & 0.432 & 0.732 & 0.996 & 0.994 \\
\hline 20 & 0.082 & 0.120 & 0.430 & 0.728 & 0.992 & 0.994 \\
\hline 30 & 0.087 & 0.121 & 0.430 & 0.725 & 0.990 & 0.991 \\
\hline 50 & 0.098 & 0.120 & 0.427 & 0.723 & 0.987 & 0.991 \\
\hline 60 & 0.093 & 0.132 & 0.342 & 0.706 & 0.914 & 0.991 \\
\hline
\end{tabular}

The last results show that the coloured chelate develops after $5 \mathrm{~min}$ and with maximum intensity, which remains so for at least 1 hour, and is independent of cerium(ш) 
concentration. This may reflect the higher strength of the chelate formed while in the absence of SDS, lower absorbancies are observed and less efficient stability is attained.

Final absorption spectra

The absorption spectra of the coloured complex and it s corresponding reagent blank are shown in (Fig. 2). The formed complex shows maximum absorption at $653 \mathrm{~nm}$, while the reagent blank gives maximum absorption at $537 \mathrm{~nm}$. The wavelength $653 \mathrm{~nm}$ of maximum absorption was still retained for subsequent work.

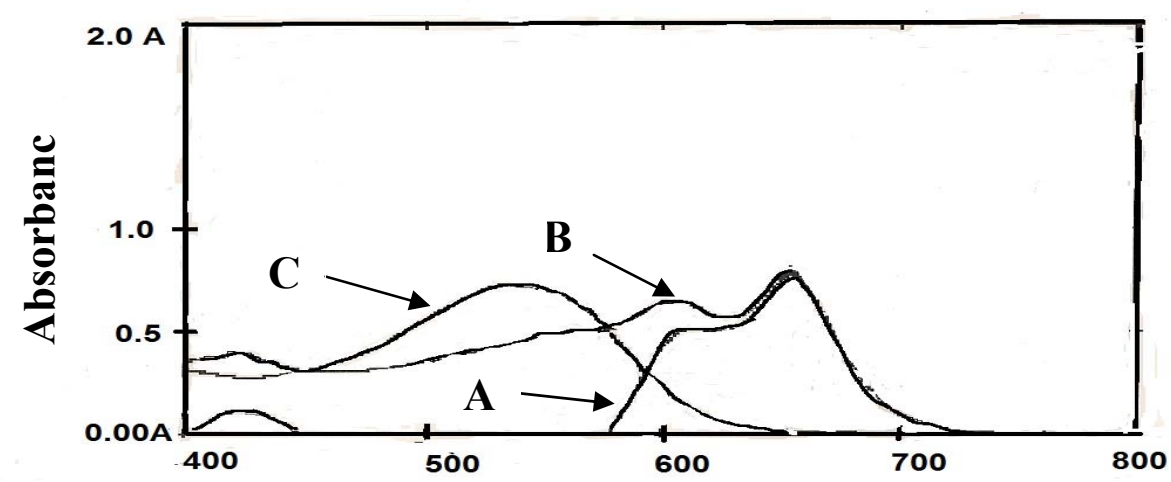

Wavelength, $\mathbf{n m}$

Fig. 2: Absorption spectra of $50 \mu \mathrm{g}$ Ce(II) treated as under optimum experimental conditions and measured (A) against blank, (B) against distilled water and

(C) blank measured against distilled water.

\section{Recommended procedure and calibration graph:}

By establishing the optimum reaction conditions, calibration graph is constructed by transferring increasing volumes of $50 \mu \mathrm{g} / \mathrm{ml}$ of Ce(ш) solution into $25-\mathrm{ml}$ volumetric flasks to cover the range $(5-100) \mu \mathrm{g} / 25 \mathrm{ml}$. Then $7 \mathrm{ml}$ of $\left(1 \times 10^{-4}\right) M$ arsenazo $w$ reagent and 1.5 $\mathrm{ml}$ of $\left(1 \times 10^{-3}\right) \mathrm{M}$ SDS and $3 \mathrm{ml}$ of glycine buffer $\mathrm{pH} 3$ and volumes are completed to the mark with distilled water. The absorbances at $653 \mathrm{~nm}$ are measured for reaction mixtures against the reagent blank prepared in the same manner but without cerium(ш). Beer's law is obeyed over the range of (5-70) $\mu \mathrm{g} \mathrm{Ce(w)} \mathrm{(Fig.} \mathrm{3).}$

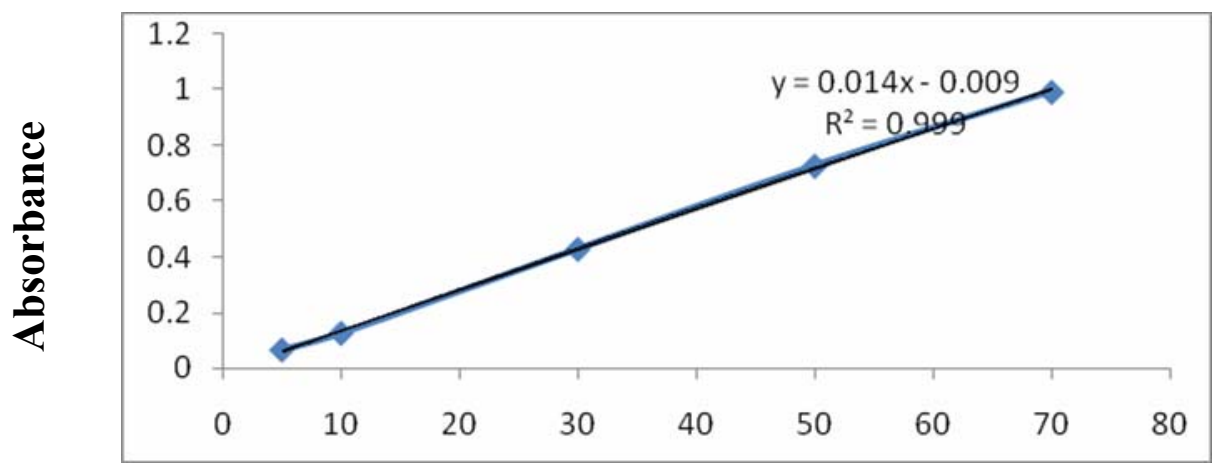

Concentration $\mu \mathrm{g} / 25 \mathrm{ml}$

Fig. 3: Calibration graph for cerium(II) determination with arsenazo II reagent. 
The average molar absorptivity of the coloured complex is calculated from the calibration graph and found to be $\left(4.99 \times 10^{4}\right) 1 . \mathrm{mol}^{-1} . \mathrm{cm}^{-1}$, while limit of detection (LOD), limit of quantitation (LOQ) (Valcarcel, 2000) are found to be $\left(66.7 \times 10^{-3}\right) \mu \mathrm{g} / \mathrm{ml}$ and $\left(92.7 \times 10^{-3}\right) \mu \mathrm{g} / \mathrm{ml}$, respectively. The results are given in Table (6). At higher concentration $(>70 \mu \mathrm{g} / 25 \mathrm{ml})$ of $\mathrm{Ce}(\amalg)$, a negative deviation was observed. Fig. 6 shows the absorption spectra for different amounts of Cerium(ш) ion: (A) $5 \mu \mathrm{g}$, (B) $10 \mu \mathrm{g}$, (C) $30 \mu \mathrm{g}$, (D) $50 \mu \mathrm{g}$, (E) $70 \mu \mathrm{g}$ and (F) $100 \mu \mathrm{g}$.

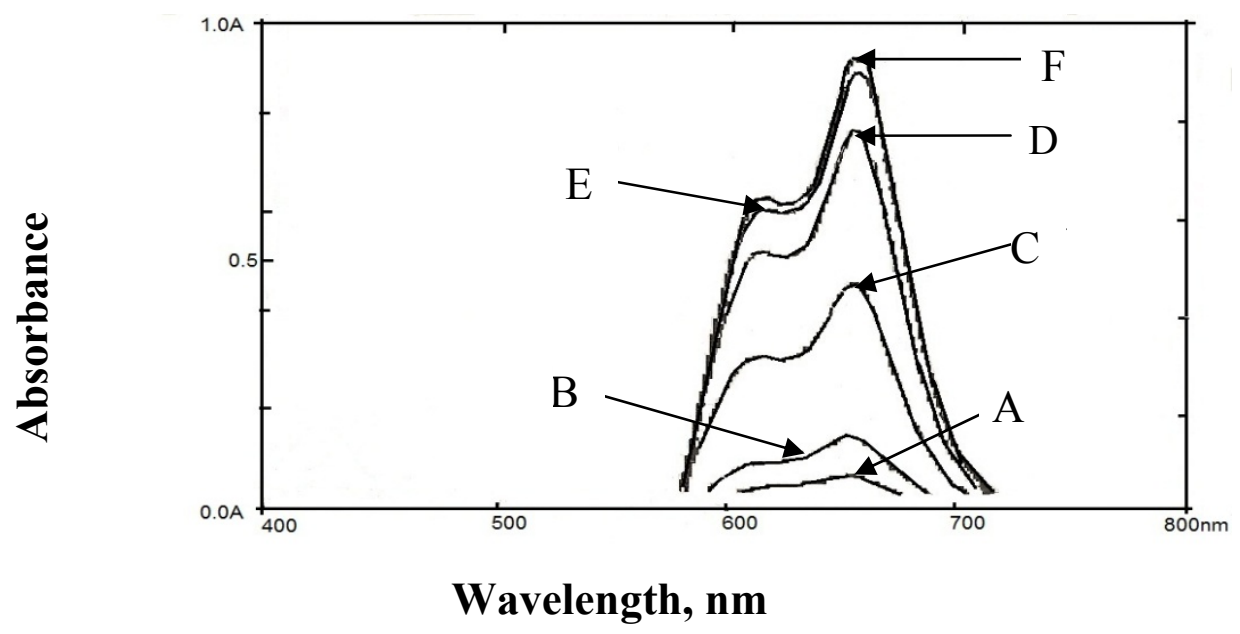

Fig. 4: Absorption spectra of different amounts ( $\mu$ g) of cerium(III) when complexed with Az III reagent: (A) $5 \mu \mathrm{g}$, (B) $10 \mu \mathrm{g}$, (C) $30 \mu \mathrm{g}$ (D) $50 \mu \mathrm{g}$, (E) $70 \mu \mathrm{g}$, (F) $100 \mu \mathrm{g}$.

\section{Accuracy and precision}

To check the accuracy and precision of the calibration graph, cerium(ш) was determined at six different concentrations.

Table 5: Accuracy and precision.

\begin{tabular}{|c|c|c|}
\hline Ce(III) taken, $(\mu \mathrm{g})$ & Recovery, \%* & Relative Standard Deviation,\% \\
\hline 10 & 100.0 & 0.0 \\
\hline 30 & 102.1 & \pm 2.1 \\
\hline 50 & 99.8 & \pm 0.2 \\
\hline
\end{tabular}

*For six determinations

The results given in Table (5) show that the accuracy and precision of the calibration graph are very satisfactory.

\section{Nature of the complex}

Job's method of continuous variations and mole-ratio method (Hargis, 1988) are used to evaluate the combining ratio between $\mathrm{Ce}(\omega)$ ion and $\mathrm{Az} ш$ chelating agent. The results 
indicated that $\mathrm{Az} ш$ reagent has reacted with $\mathrm{Ce}(ш)$ in a 2:1 ratio, and the SDS ratio to complex is 2:1 (mole - ratio method).

Therefore, the structural formula of the chelate may be postulated as follows:

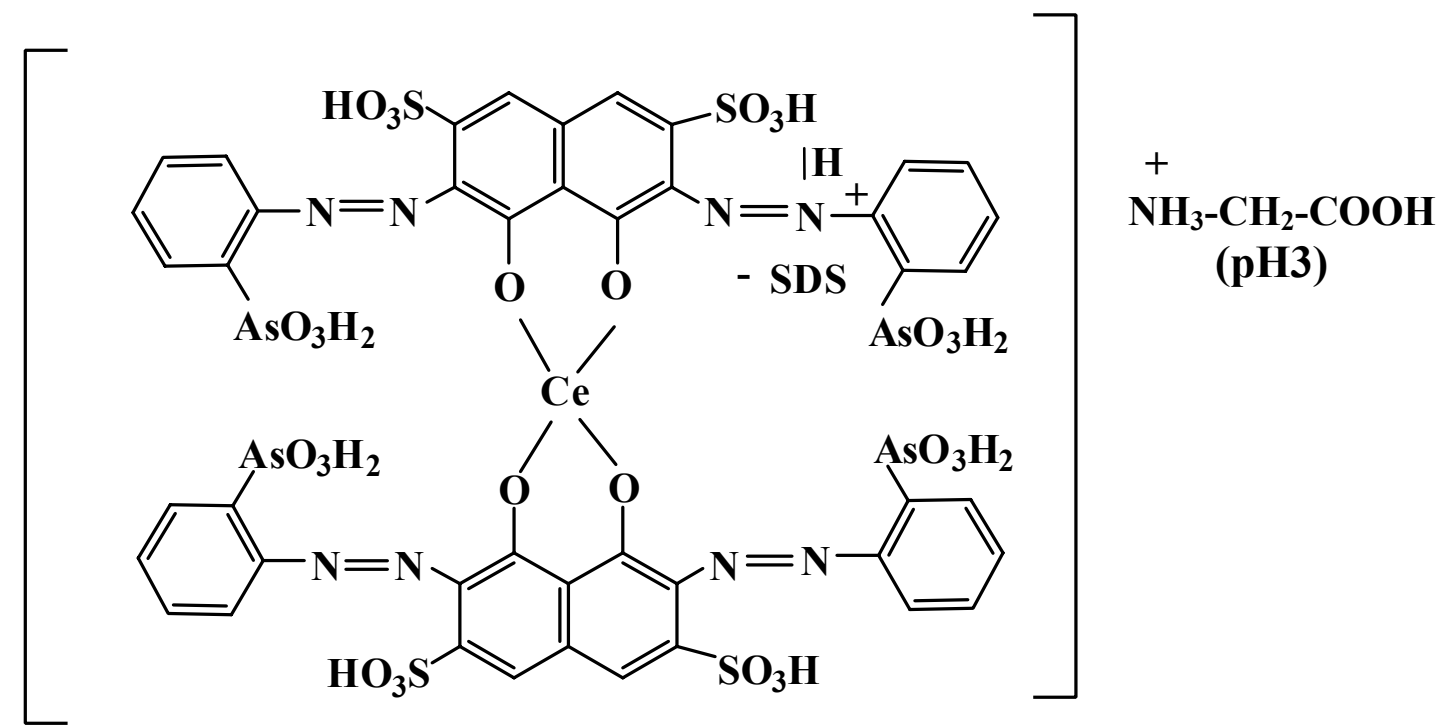

\section{Scheme 2: Ce(III) -Az III chelate}

The constant stability of the postulated chelated complex is $2.153 \times 10^{12} M^{-2}$

\section{Effect of organic solvents}

Different organic solvents have been examined to evaluate their effects on the spectrum of the coloured chelate formed by mixing $50 \mu \mathrm{g}$ of $\mathrm{Ce}(\omega)$ solution with $7 \mathrm{ml}$ of $\left(1 \times 10^{-4} \mathrm{M}\right)$ arsenazo $ш, 1.5 \mathrm{ml}$ of SDS and $3 \mathrm{ml}$ of glycine buffer $\mathrm{pH} 3$ and diluted to the mark with different organic solvents in $25-\mathrm{ml}$ volumetric flasks.

The results illustrated in Table (6) and Fig. (5), show that there is no significant change in the spectral position (with reference to water) but a decrease in intensity of absorbance is observed in formic acid, so water is still recommended for dilution in the proposed method because of availability and low cost.

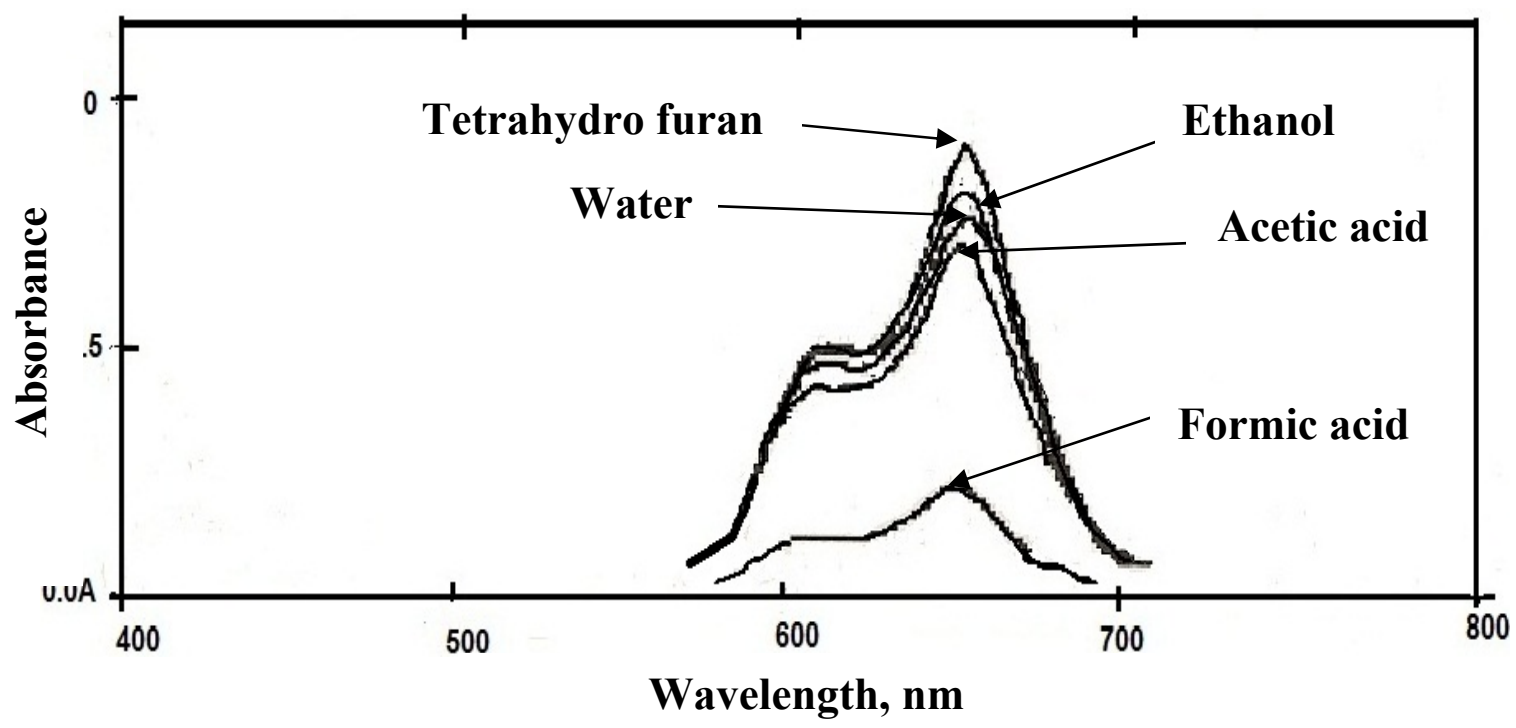

Fig. 5: Effect of solvents on spectral properties of $\mathrm{Az}$ II-Ce(II) chelated complex 
Table 6: Effect of organic solvents.

\begin{tabular}{|c|c|c|c|c|}
\hline Solvents & Imax, nm & $\mathbf{A}_{\mathbf{B}}^{\mathrm{S}}$ & $\mathbf{A}_{w}^{B}$ & \& $1 . \mathrm{mol}^{-1} \mathrm{~cm}^{-1}$ \\
\hline Ethanol & 653 & 0.834 & 0.109 & $5.87 \times 10^{4}$ \\
\hline Tetra hydro furan & 653 & 0.913 & 0.049 & $6.43 \times 10^{4}$ \\
\hline Formic acid & 652 & 0.229 & 0.039 & $1.61 \times 10^{4}$ \\
\hline Acetic acid & 652 & 0.718 & 0.049 & $5.06 \times 10^{4}$ \\
\hline Water & 653 & 0.728 & 0.022 & $5.13 \times 10^{4}$ \\
\hline
\end{tabular}

\section{Study of Interferences}

The recommended procedure was applied to test the selectivity for the spectrophotometric determination of $\mathrm{Ce}(ш)$ using arsenazo $ш$ reagent by the study of interfering effects of foreign species in the determination of $50 \mu \mathrm{g}$ of $\mathrm{Ce}(\mathrm{\omega})$ in presence of each interfering ion. The results are shown in Table (7).

Table 7: Study of interferences

\begin{tabular}{|c|c|c|c|}
\hline Foreign ion & Form added as & Amount added, $\mu \mathrm{g}$ & Interferences, $\%$ \\
\hline $\mathrm{Al}^{3+}$ & $\mathrm{AlCl}_{3} \cdot 6 \mathrm{H}_{2} \mathrm{O}$ & $\begin{array}{c}50 \\
100 \\
500 \\
1000\end{array}$ & $\begin{array}{l}+18.40 \\
+17.63 \\
+22.01 \\
+27.16\end{array}$ \\
\hline $\mathrm{Te}^{4+}$ & $\mathrm{TeO}_{2}$ & $\begin{array}{c}50 \\
100 \\
1000 \\
2500\end{array}$ & $\begin{array}{c}+1.97 \\
+3.42 \\
+15.50 \\
-23.65\end{array}$ \\
\hline $\mathrm{Bi}^{3+}$ & $\mathrm{Bi}\left(\mathrm{NO}_{3}\right)_{3}$ & $\begin{array}{c}50 \\
100 \\
500 \\
1000\end{array}$ & $\begin{array}{c}+1.80 \\
+1.30 \\
-0.92 \\
-15.90\end{array}$ \\
\hline $\mathrm{Be}^{2+}$ & $\mathrm{BeSO}_{4}$ & $\begin{array}{c}50 \\
100 \\
500\end{array}$ & $\begin{array}{c}-2.60 \\
-10.50 \\
-42.00\end{array}$ \\
\hline $\mathrm{Ni}^{2+}$ & $\mathrm{NiCl}_{2} \cdot 6 \mathrm{H}_{2} \mathrm{O}$ & $\begin{array}{c}50 \\
100 \\
500 \\
1000 \\
2500\end{array}$ & $\begin{array}{l}+1.30 \\
+2.50 \\
+0.53 \\
-3.95 \\
-11.80\end{array}$ \\
\hline $\mathrm{Th}^{4+}$ & $\mathrm{Th}\left(\mathrm{NO}_{3}\right)_{4} \cdot 6 \mathrm{H}_{2} \mathrm{O}$ & $\begin{array}{c}50 \\
100\end{array}$ & $\begin{array}{l}-30.30 \\
-45.40\end{array}$ \\
\hline $\mathrm{Cr}^{3+}$ & $\mathrm{CrCl}_{3}$ & $\begin{array}{c}50 \\
100 \\
500\end{array}$ & $\begin{array}{l}-45.40 \\
-44.10 \\
-58.40\end{array}$ \\
\hline $\mathrm{V}^{+5}$ & $\mathrm{NH}_{4} \mathrm{VO}_{3}$ & $\begin{array}{c}50 \\
100\end{array}$ & $\begin{array}{l}-12.45 \\
-4.60\end{array}$ \\
\hline $\mathrm{Sn}^{2+}$ & $\mathrm{SnCl}_{2}$ & $\begin{array}{c}50 \\
100 \\
500\end{array}$ & $\begin{array}{c}1.94 \\
+1.42 \\
-0.38\end{array}$ \\
\hline $\mathrm{Cd}^{2+}$ & $\mathrm{Cd}\left(\mathrm{CH}_{3} \mathrm{COO}\right)_{2} \cdot 2 \mathrm{H}_{2} \mathrm{O}$ & $\begin{array}{c}50 \\
100 \\
500\end{array}$ & $\begin{array}{l}+0.77 \\
-1.30 \\
+0.39\end{array}$ \\
\hline
\end{tabular}


Spectrophotometric Determination of Cerium.......

\begin{tabular}{|c|c|c|c|}
\hline $\mathrm{Fe}^{3+}$ & $\mathrm{Fe}\left(\mathrm{NO}_{3}\right)_{3} .9 \mathrm{H}_{2} \mathrm{O}$ & $\begin{array}{c}50 \\
100 \\
500\end{array}$ & $\begin{array}{l}-74 \\
-76 \\
-80 \\
\end{array}$ \\
\hline $\mathrm{Fe}^{2+}$ & $\mathrm{Fe}\left(\mathrm{NH}_{4}\right)_{2}\left(\mathrm{SO}_{4}\right)_{2} \cdot 6 \mathrm{H}_{2} \mathrm{O}$ & $\begin{array}{c}50 \\
100 \\
500 \\
\end{array}$ & $\begin{array}{l}-3.43 \\
-8.94 \\
-3.70 \\
\end{array}$ \\
\hline $\mathrm{Pb}^{2+}$ & $\mathrm{Pb}\left(\mathrm{NO}_{3}\right)_{2}$ & $\begin{array}{c}50 \\
100\end{array}$ & $\begin{array}{c}-7.80 \\
-15.10\end{array}$ \\
\hline $\mathrm{Hg}^{2+}$ & $\mathrm{Hg}\left(\mathrm{NO}_{3}\right)_{2}$ & $\begin{array}{c}50 \\
100 \\
500\end{array}$ & $\begin{array}{l}4.55 \\
1.04 \\
3.50\end{array}$ \\
\hline $\mathrm{Mg}^{2+}$ & $\mathrm{MgSO}_{4} \cdot 7 \mathrm{H}_{2} \mathrm{O}$ & $\begin{array}{c}50 \\
100 \\
500\end{array}$ & $\begin{array}{c}3.64 \\
2.73 \\
-1.17\end{array}$ \\
\hline $\mathrm{Co}^{2+}$ & $\mathrm{Co}\left(\mathrm{NO}_{3}\right)_{2} \cdot 6 \mathrm{H}_{2} \mathrm{O}$ & $\begin{array}{c}50 \\
100 \\
500\end{array}$ & $\begin{array}{c}+13.25 \\
4.20 \\
2.60\end{array}$ \\
\hline $\mathrm{Ca}^{2+}$ & $\mathrm{CaCl}_{2}$ & $\begin{array}{c}50 \\
100 \\
500 \\
\end{array}$ & $\begin{array}{l}3.15 \\
5.52 \\
3.93\end{array}$ \\
\hline $\mathrm{Li}^{+}$ & $\mathrm{Li}_{2} \mathrm{SO}_{4} \cdot \mathrm{H}_{2} \mathrm{O}$ & $\begin{array}{c}50 \\
100 \\
500 \\
\end{array}$ & $\begin{array}{c}0.66 \\
0.66 \\
-5.60\end{array}$ \\
\hline $\mathrm{Cu}^{2+}$ & $\mathrm{CuSO}_{4}$ & $\begin{array}{c}50 \\
100 \\
500\end{array}$ & $\begin{array}{c}+5.28 \\
10.30 \\
-21.90\end{array}$ \\
\hline $\mathrm{W}^{6+}$ & $\mathrm{Na}_{2} \mathrm{WO}_{4} \cdot 2 \mathrm{H}_{2} \mathrm{O}$ & $\begin{array}{c}50 \\
100 \\
500 \\
\end{array}$ & $\begin{array}{c}-4.63 \\
-6.56 \\
+5.66 \\
\end{array}$ \\
\hline $\mathrm{Ba}^{2+}$ & $\mathrm{BaCl}_{2} \cdot 2 \mathrm{H}_{2} \mathrm{O}$ & $\begin{array}{c}50 \\
100 \\
500\end{array}$ & $\begin{array}{l}+3.35 \\
-0.128 \\
+2.06 \\
\end{array}$ \\
\hline $\mathrm{Mn}^{2+}$ & $\mathrm{MnCl}_{2} \cdot 4 \mathrm{H}_{2} \mathrm{O}$ & $\begin{array}{c}50 \\
100 \\
500\end{array}$ & $\begin{array}{l}-6.95 \\
-5.41 \\
-4.38\end{array}$ \\
\hline $\mathrm{Na}^{+}$ & $\mathrm{NaCl}$ & $\begin{array}{c}50 \\
100 \\
500\end{array}$ & $\begin{array}{l}+0.13 \\
+3.91 \\
+0.63\end{array}$ \\
\hline $\mathrm{K}^{+}$ & $\mathrm{KI}$ & $\begin{array}{c}50 \\
100 \\
500\end{array}$ & $\begin{array}{c}+0.89 \\
+10.97 \\
+5.99\end{array}$ \\
\hline $\mathrm{Zn}^{2+}$ & $\mathrm{Zn}\left(\mathrm{OOCCH}_{3}\right)_{2} 2 \mathrm{H}_{2} \mathrm{O}$ & $\begin{array}{c}50 \\
100\end{array}$ & $\begin{array}{l}-3.94 \\
-3.08\end{array}$ \\
\hline $\mathrm{Se}^{4+}$ & $\mathrm{SeO}_{2}$ & $\begin{array}{c}50 \\
100 \\
500 \\
\end{array}$ & $\begin{array}{l}+1.79 \\
-0.77 \\
+2.68\end{array}$ \\
\hline $\mathrm{Zr}^{4+}$ & $\mathrm{ZrOCl}_{2} \cdot 6 \mathrm{H}_{2} \mathrm{O}$ & 50 & -12.60 \\
\hline $\mathrm{Sr}^{2+}$ & $\mathrm{SrCl}_{2}$ & $\begin{array}{l}100 \\
500\end{array}$ & $\begin{array}{l}-5.99 \\
+4.72\end{array}$ \\
\hline $\mathrm{Mo}^{6+}$ & $\left(\mathrm{NH}_{4}\right)_{6} \cdot \mathrm{Mo}_{7} \mathrm{O}_{24} \cdot 4 \mathrm{H}_{2} \mathrm{O}$ & $\begin{array}{c}50 \\
100\end{array}$ & $\begin{array}{l}+1.66 \\
-3.95\end{array}$ \\
\hline $\mathrm{SCN}^{-}$ & $\mathrm{KSCN}$ & $\begin{array}{c}50 \\
100 \\
500 \\
\end{array}$ & $\begin{array}{l}+5.04 \\
+1.01 \\
-0.88 \\
\end{array}$ \\
\hline $\mathrm{Br}^{-}$ & $\mathrm{KBr}$ & $\begin{array}{c}50 \\
100 \\
500\end{array}$ & $\begin{array}{c}5.63 \\
-0.86 \\
0.0\end{array}$ \\
\hline $\mathrm{HCO}_{3}^{-}$ & $\mathrm{NaHCO}_{3}$ & 100 & -1.96 \\
\hline
\end{tabular}


Sadallah T. Sulaiman et al.

\begin{tabular}{|c|c|c|c|}
\hline & & 500 & -1.84 \\
\hline $\mathrm{S}_{2} \mathrm{O}_{3}^{-2}$ & 50 & -4.28 \\
& $\mathrm{Na}_{2} \mathrm{~S}_{2} \mathrm{O}_{3} \cdot 5 \mathrm{H}_{2} \mathrm{O}$ & 100 & -1.84 \\
\hline $\mathrm{BrO}_{3}^{-}$ & $\mathrm{NaBrO}_{3}$ & 50 & 1.22 \\
& & 100 & -0.73 \\
& & 500 & -0.43 \\
\hline $\mathrm{SO}_{3}^{-2}$ & $\mathrm{Na}_{2} \mathrm{SO}_{3}$ & 50 & -0.39 \\
& & 100 & +0.26 \\
& & 500 & -0.66 \\
\hline $\mathrm{BO}_{3}^{-{ }^{-3}}$ & $\mathrm{H}_{3} \mathrm{BO}_{3}$ & 50 & -2.94 \\
& & 100 & -8.45 \\
& & 500 & -5.39 \\
\hline $\mathrm{SO}_{4}^{-2}$ & $\mathrm{CdSO}_{4}$ & 50 & +3.94 \\
& & 100 & 0.74 \\
\hline $\mathrm{CO}_{3}^{-2}$ & & 500 & -5.42 \\
\hline & $\mathrm{Na}_{2} \mathrm{CO}_{3}$ & 50 & -30.70 \\
\hline
\end{tabular}

The results in the above table indicate that a high error is observed in the case of $\mathrm{Al}^{+3}, \mathrm{Te}^{+4}, \mathrm{Th}^{4+}, \mathrm{Be}^{2+}, \mathrm{Cr}^{3+}, \mathrm{Fe}^{3+}, \mathrm{Pb}^{2+}$ and $\mathrm{Zr}^{4+}$ due to the competition of these ions with $\mathrm{Ce}^{3+}$ for the reagent (appearance of blue- violet colour) there by depleting the reagent available for the $\mathrm{Ce}^{3+}$ ion.

\section{Application of the method}

This method has been applied to the determination of cerium ion in synthetic composite mixture firstly and in sea water secondly. The results are listed below:

\section{Determination of cerium(II) in synthetic composite mixture}

Mixtures containing cations and anions and $50 \mu \mathrm{g}$ of cerium (ш) have been prepared and analyzed for cerium. The results are given in Table (8).

Table 8 :Recovery of Cerium(II) in synthetic composite mixture.

\begin{tabular}{|c|c|c|c|}
\hline Ion added & Amount added, $\boldsymbol{\mu g}$ & Ce(w) added, $\boldsymbol{\mu g}$ & Recovery, $\%$ \\
\hline $\mathrm{Se}^{4+}, \mathrm{Te}^{4+}, \mathrm{Mg}^{2+}, \mathrm{Br}^{-}$, & 50 & 50 & 100 \\
$\mathrm{SO}_{3}{ }^{2-}(\mathrm{I})$ & 100 & 50 & 100.7 \\
\hline $\mathrm{Ni}^{2+}, \mathrm{Bi}^{3+}, \mathrm{Li}^{+}, \mathrm{SO}_{4}{ }^{2-}$ & 50 & 50 & 91.4 \\
$(\mathrm{II})$ & 100 & 50 & 85.6 \\
\hline $\mathrm{Na}^{+}, \mathrm{Mg}^{2+}, \mathrm{SCN}^{-}, \mathrm{SO}_{3}{ }^{2-}$ & 50 & 50 & 119.6 \\
$(\mathrm{III})$ & 100 & 50 & 100 \\
\hline $\mathrm{Ni}^{2}, \mathrm{Ca}^{2+}, \mathrm{SO}_{4}{ }^{2-}, \mathrm{Br}^{-}(\mathrm{IV})$ & 50 & 50 & 98.4 \\
& 100 & 50 & 103.6 \\
\hline
\end{tabular}

Other composite mixtures are tried but with unsuccessful results. It can be observed that the method gives fair recovery of cerium (ш), and applicable for case ( I) and (IV).

\section{Determination of cerium (II) in sea water}

Table (9) shows the results obtained for the determination of $\mathrm{Ce}(ш)$ in sea water which is prepared in the laboratory (Henriksen, 1965). 
Table 9: Determination of cerium(II) in sea water samples.

\begin{tabular}{|c|c|c|}
\hline ml of sample & Ce(II) added, $\boldsymbol{\mu g}$ & Recovery, ${ }^{*} \%$ \\
\hline 0.5 & 10 & 152.680 \\
& 30 & 147.198 \\
& 50 & 92.127 \\
\hline 1.0 & 10 & 125.168 \\
& 30 & 108.500 \\
& 50 & 89.519 \\
\hline 1.5 & 10 & 118.120 \\
& 30 & 108.400 \\
& 50 & 87.299 \\
\hline
\end{tabular}

*Average of three determinations.

The results in Table (9) indicate that the method should be preceded by a separation step for cerium (ш) before determination.

\section{Comparison of the methods}

The comparison between the analytical variables of the present method with those of another method. The data were given in Table (10).

Table 10: Comparison of the method.

\begin{tabular}{|c|c|c|}
\hline Analytical parameters & Present method & $\begin{array}{l}\text { Literature method } \\
\text { (Marczenko, 2000) }\end{array}$ \\
\hline $\mathrm{pH}$ & 3.00 & $2.3-2.7$ \\
\hline Molar absorptivity $\left(\mathrm{L} \cdot \mathrm{mol}^{-1} \cdot \mathrm{cm}^{-1}\right)$ & $4.99 \times 10^{4}$ & $5.6 \times 10^{4}$ \\
\hline Effect of surfactant & $1.5 \mathrm{ml}$ of $1 \times 10^{-3} M \mathrm{SDS}$ & 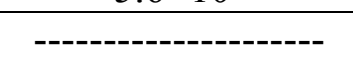 \\
\hline Beer s law range ( ppm) & $0.2-2.8$ & --------------------- \\
\hline Determination coefficient $\left(\mathrm{r}^{2}\right)$ & 0.9994 & 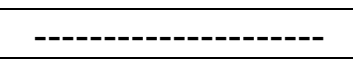 \\
\hline $\mathrm{K}\left(\mathrm{L}_{\mathrm{mol}} \mathrm{m}^{-1}\right)$ & $0.2153 \times 10^{13}$ & -------- \\
\hline Amount of reagent & $7 \mathrm{ml}$ of $1 \times 10^{-4} M$ & 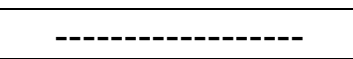 \\
\hline$\lambda_{\max }(\mathrm{nm})$ & 653 & 650 \\
\hline Sandell's index $\left(\mu \mathrm{g} . \mathrm{cm}^{-2}\right)$ & $28.08 \times 10^{-4}$ & -------------------- \\
\hline
\end{tabular}

Various analytical parameters are missed from the literature method.

The present method differs from the literature method in two main things:

(a) the fantastic introduction of SDS surfactant.

(b) the detailed optimization of experimental conditions that has not been established yet.

\section{REFERENCES}

Alessandro, (2002). "Catalysis by Ceria and Related Materials". Imperial College Press, ISBN 1860942997. http://books.google.com/id=X2z9WdN3-Wgc, pp. 6-11.

Ayglgek, A.; Rakicioglu, Y. (1996). Fluorimetric trace determination of cerium(ш) with sodium triphosphate. Talanta, 43(11), 1983- 1988.

Franciszek, B.; Sroka, B. (2001). Spectrophotometric determination of ampicillin and amoxicillin with Ce(IV) and arsenazo ш. Chem. Anal., 46(1), 69. 
Hammond, C.R. (2000). "Handbook of Chemistry and Physics". 81st ed, CRC Press. (Internet Version).

Hargis, L.G. (1988). "Analytic Chemistry Principles and Techniques". Prentice-Hall Intrenational Ltd., London, pp. 424-426.

Henriksen, A. (1965). An automatic method for determining nitrate and nitrite in fresh and saline waters. Analyst, 90(38), 88.

Internet, (2009). Chemical reactions of cerium. Webelements, https ://www.webelemennts. $\mathrm{com} /$ cerium / chemistry. Html. 06-06.

Karami, H.; Mousavi, F.; Shamsipur, M.; Yavari, I.; Alizadeh, A.A. (2003). A new ionselective electrode for potentiometric determination of $\mathrm{Ce}(\amalg)$. Anal. Lett., 36(6), 1065-1078.

Marczenko, Z.; Balcerzak, M. (2000). "Preconcentration and Spectrophotometry in inorganic Analysis ". Ellis Horwood Ltd., Chichester, (CD- ROM). 442 p.

Perrin, D.D., Dempsey, B. (1974). "Buffers for $\mathrm{pH}$ and Metal Ion Control". Chapman and Halltd., London, pp.128-136.

Valcarcel, M. (2000). "Principles of Analytical Chemistry". Spring-Verlag, Berlin, 68 p.

Shamsipur, M.; Yousefi, M.; Ghasemi, Z.; Hagiaha, B.L.; Gnjali, M.R. (2002). Separation and preconcentration trace amounts of cerium (ш) on octadecyl silica membrane disesmodified with 1,3,5-trithiocyclohexane and its spectrophotometric determination by arsenazo ш. Sep. Sci. Technol., 37, 3525-3534.

Zhu, X.; Zhang, Y.; Gong, A.; Zhang, X. (2008). Flow injection kinetic spectrophotometric determination of cerium based on the decolorization reaction between arsenazo ш and cerium (IV). Spectroscopy Lett., 41(5), 237-241. 